\title{
Clinical value of exfoliative cytology in neoplasia of the lung
}

\author{
G. S. ANDREWS AND T. ROSSER \\ From the Departments of Pathology and Thoracic Surgery, St. Woolos Hospital, Newport, Mon.
}

The examination of various body fluids and secretions for malignant cells has now become a well recognized procedure in clinical laboratories. The method certainly has its supporters and enthusiasts, who are obviously encouraged by the frequent finding of positive cases. In neoplasia of the lung, however, the published figures of positive results vary from $20.1 \%$ (Bamforth and Osborn, 1958) to $83.2 \%$ (Williams, 1961) for sputum, and $21 \%$ (Boucot and Sokoloff, 1955) to $88.8 \%$ (Clerf and Herbut, 1950) for bronchial secretions, although higher figures have been recorded where sputum-inducing agents have been employed.

The wide variation in these figures must be explained, at least partially, by the selection of patients and by differences in technique, especially variation in the number of specimens examined. It is undoubtedly satisfying to identify malignant cells, but this often requires a prolonged search and considerable knowledge and experience, especially if diagnosis is based on the recognition of individual cells, and it is worth considering whether or not such detailed examinations are of significant value to either patient or clinician.

The establishment of a reliable test for the early diagnosis of cancer is constantly being sought, and many clinicians hoped that the presence of malignant cells in the sputum might be detected early in the course of carcinoma of the bronchus, thus providing a simple screening test. Although, unfortunately, this has sometimes led to the examination being allowed to deteriorate into a 'routine' procedure on all patients admitted to hospital, it is still a matter worth investigating.

In this paper we have reviewed patients who have had sputum, bronchial secretions, or pleural fluid examined for malignant cells and in whom a diagnosis has been firmly established, in order to see if such an examination can be regarded as a reliable screening test in the early diagnosis of cancer and to discover the significant value to clinician and patient of the finding of malignant cells in this material.
The patients have been under review for two to seven years.

\section{MATERIAL AND METHODS}

We have reviewed 736 patients who were examined for malignant cells in the sputum, bronchial secretions or pleural fluid and in whom a clear diagnosis had been established. These included 223 cases of bronchial carcinoma and 10 cases of secondary carcinoma of the lung. The type of examination carried out on all the patients is shown in Table I.

\section{T A B L E I}

ANALYSIS OF MATERIAL EXAMINED IN THE 736 PATIENTS REVIEWED

\begin{tabular}{|c|c|}
\hline Cases & Examination \\
\hline $\begin{array}{r}349 \\
60 \\
4 \\
283 \\
2 \\
23 \\
15\end{array}$ & $\begin{array}{l}\text { Sputum only } \\
\text { Bronchial secretions only } \\
\text { Pleural fluid only } \\
\text { Sputum and bronchial secretions } \\
\text { Bronchial secretions and pleural fluid } \\
\text { Sputum and pleural fluid } \\
\text { Sputum, bronchial secretions, and pleural fluid }\end{array}$ \\
\hline
\end{tabular}

Histological preparations of sputum were made by collecting directly into Schaudinn's fixative, prepared by mixing two parts of saturated mercuric chloride and one part of absolute alcohol immediately before use. The specimen was left in fixative until it was firm enough to be handled with forceps, then wrapped in tissue paper, transferred to a cassette and dehydrated, cleared, and embedded through graded alcohols, benzene, and paraffin wax in the automatic tissue processor. During blocking, the specimen floated to the top of the wax and consequently this top surface was used for cutting. Blocks were well cut down and the sections were taken from the centre of the material. These were routinely stained with haematoxylin and eosin. This method was preferred because of the ease with which the material was handled and because the histological results are directly comparable with those of tissue sections.

During examination of the bronchial tree through the bronchoscope, bronchial secretions were collected into a small trap tube attached to the suction apparatus. The secretions were sucked from the most suspicious area. They were fixed in freshly prepared 
Schaudinn's solution, which was sucked into the tube through the suction apparatus. They were transferred to a small bottle. left in fixative overnight. and then transferred to a small, thin-walled test tube in which they were hand-processed through the alcohols and benzene, being centrifuged and decanted between the solutions. Four changes of paraffin wax were used. and the final paraffin was hardened by placing the tube in cold water. The tubes were placed in the refrigerator to contract the wax and broken to release the block.

Pleural fluid for cytological examination was collected into fresh Schaudinn's solution and, depending upon the amount of precipitate, was processed as either sputum or bronchial secretions.

The diagnosis of malignant cells was based on the usual criteria of cell size and shape, and nuclear size. pyknosis, aberration, and mitoses. When malignant cells are found together in clumps. as they usually are, the diagnosis is simple and an assessment of the type of growth can often be made with confidence. The recognition of individual malignant cells is, however, a different matter, and cells from areas of squamous metaplasia, especially in the presence of infection such as bronchiectasis, can give rise to considerable difficulties. Cells from regenerating ep:thelium after bronchoscopy can also lead to confusion. and for this reason sputum was not re-examined until a week had elapsed after bronchoscopy.

At first malignant cells were only reported if the cytological diagnosis was certain, as it was thought that to describe cells as suspicious or doubtful in a case that was already difficult would not help the clinician. However, with the growth of mutual confidence, it was found that there was a place for the reporting of doubtful positives, and this could in many cases be of considerable value to the clinician. especially if a clear understanding existed between the clinician and the pathologist. These suspicious cases have been included among the positive results. It must be admitted that the finding of malignant cells in the sputum of a patient with no evidence of unilateral disease may give rise to an embarrassing clinical problem. In fact the majority of cases in this series had radiological evidence of unilateral disease, but a special attempt was made to study those in whom cytological evidence of malignancy was the first finding to see if the patient obtained any benefit from such an apparently early diagnosis.

\section{RESULTS}

FALSE POSITIVES In the 503 cases with no evidence of neoplasia of the lungs, false positives were reported in four $(0.8 \%)$. One was diagnosed from bronchial secretions, which were examined in 208 of the cases and thus gave a false positive rate of $0.48 \%$. The error was made in the early days, and a review of the slide shows that it is extremely unlikely that a positive diagnosis would now be made.

The other three false positives were diagnosed $\frac{\bar{m}}{\bar{s}}$ from sputum, which was examined in 458 cases. giving a false positive rate of $0.65 \%$. The false positive sample rate of sputum was considerably less than $0.65 \%$, as in many cases several samples $\vec{\circ}$ of sputum were examined.

Examination of the three false positives individually shows that in one case one sputum only $\overrightarrow{\vec{z}}$ out of three was reported positive, and broncho- $x$ scopy, bronchial secretions, and biopsy were all $\vec{\bullet}$ negative ; lobectomy was performed for bronchi- $\omega$ ectasis with lung abscess.

In the second case, one sputum out of four was? reported positive, and it was described as doubtful. The patient had an enlarged cervical lymph node, $\vec{z}$ which was eventually removed and showed nog evidence of malignancy.

In the third case, two sputa were reported as suspicious, and a further four were all negative. ${ }^{+}$ The patient was an asthmatic with cardiac failure. O and there appears to have been no good clinical reason for entertaining a diagnosis of carcinoma.

Examination of these false positives reveals that no great harm came to the patient as a result.

It is interesting that there were no false positives $\overrightarrow{\vec{B}}$ in the 26 pleural fluids examined from non-malig- $\frac{0}{3}$ nant cases. It is well known that pleural endothelial cells may undergo bizarre changes and give rise to difficulties in diagnosis. Perhaps because of this. extreme caution was exercised.

CARCINOMA OF BRONCHUS In the 223 cases of bronchial carcinoma, sputum was examined in 205 , bronchial secretions in 148, and pleural eflu-ô sions in 17. Malignant cells were diagnosed in the sputum of 47 cases $(23 \%)$, in the bronchial secre-o tions of 30 cases $(20 \%)$, and in the pleural fluid of six cases $(35 \%)$.

We considered these figures to be disappointingly low when compared with the results in somes of the other series. The way in which these results 0 were distributed is shown in Table II, and is of $\mathrm{W}^{2}$ interest.

This table shows that the majority of cases (126) were diagnosed confidently on bronchoscopic findings and biopsy examination. Exfoliative cytology was not really required.

In 51 cases where the usual clinical investiga-o tions were negative the clinician received help from exfoliative cytology in $14(27 \%)$, those posi- $-\frac{\mathrm{D}}{\mathrm{D}}$ tive being five secretions and nine sputa.

There were 46 cases which could not be properly investigated, usually because of their pooro 
TABLE II

ANALYSIS OF THE DISTRIBUTION OF RESULTS IN 223 CASES OF CARCINOMA OF THE BRONCHUS

\begin{tabular}{|c|c|c|c|c|c|}
\hline \multirow{2}{*}{$\begin{array}{l}\text { Broncho- } \\
\text { scopy }\end{array}$} & \multirow[b]{2}{*}{ Biopsy } & \multirow{2}{*}{$\begin{array}{l}\text { Bronchial } \\
\text { Secretions }\end{array}$} & \multicolumn{3}{|c|}{ Sputum } \\
\hline & & & $\begin{array}{c}\text { Posi- } \\
\text { tive }\end{array}$ & $\underset{\text { tive }}{\text { Nega- }}$ & $\begin{array}{l}\text { Not } \\
\text { Exam- } \\
\text { ined }\end{array}$ \\
\hline \multirow[t]{3}{*}{$\overline{\text { Positive } 123}$} & $\underset{61}{P o s i t i v e}$ & $\begin{array}{lr}\text { Positive } & 19 \\
\text { Negative } & 28 \\
\text { Not examined } & 14\end{array}$ & $\begin{array}{l}6 \\
4 \\
4\end{array}$ & $\begin{array}{l}10 \\
18 \\
10\end{array}$ & $\begin{array}{l}3 \\
6 \\
0\end{array}$ \\
\hline & $\begin{array}{l}\text { Negative } \\
23\end{array}$ & $\begin{array}{lr}\text { Positive } & 1 \\
\text { Negative } & 18 \\
\text { Not examined } & 4\end{array}$ & $\begin{array}{l}0 \\
5 \\
1\end{array}$ & $\begin{array}{r}1 \\
11 \\
3\end{array}$ & $\begin{array}{l}0 \\
2 \\
0\end{array}$ \\
\hline & $\begin{array}{l}\text { Not } \\
\text { examined } \\
39\end{array}$ & $\begin{array}{lr}\text { Positive } & 5 \\
\text { Negative } & 27 \\
\text { Not examined } & 7\end{array}$ & $\begin{array}{l}2 \\
7 \\
0\end{array}$ & $\begin{array}{r}3 \\
18 \\
7\end{array}$ & $\begin{array}{l}0 \\
2 \\
0\end{array}$ \\
\hline \multirow[t]{3}{*}{$\begin{array}{l}\text { Negative } \\
54\end{array}$} & $\underset{3}{\text { Positive }}$ & $\begin{array}{ll}\text { Positive } & 0 \\
\text { Negative } & 3 \\
\text { Not examined } & 0\end{array}$ & $\begin{array}{l}0 \\
0 \\
0\end{array}$ & $\begin{array}{l}0 \\
2 \\
0\end{array}$ & $\begin{array}{l}0 \\
1 \\
0\end{array}$ \\
\hline & $\begin{array}{l}\text { Negative } \\
4\end{array}$ & $\begin{array}{ll}\text { Positive } & 0 \\
\text { Negative } & 4 \\
\text { Not examined } & 0\end{array}$ & $\begin{array}{l}0 \\
1 \\
0\end{array}$ & $\begin{array}{l}0 \\
3 \\
0\end{array}$ & $\begin{array}{l}0 \\
0 \\
0\end{array}$ \\
\hline & $\begin{array}{l}\text { Not } \\
\text { examined } \\
47\end{array}$ & $\begin{array}{lr}\text { Positive } & 5 \\
\text { Negative } & 38 \\
\text { Not examined } & 4\end{array}$ & $\begin{array}{l}1 \\
5 \\
2\end{array}$ & $\begin{array}{r}3 \\
31 \\
1\end{array}$ & $\begin{array}{l}1 \\
3 \\
0\end{array}$ \\
\hline \multirow[t]{3}{*}{$\begin{array}{l}\text { Not } \\
\text { examined } \\
46\end{array}$} & $\begin{array}{c}\text { Positive } \\
0\end{array}$ & $\begin{array}{ll}\text { Positive } & 0 \\
\text { Negative } & 0 \\
\text { Not examined } & 0\end{array}$ & $\begin{array}{l}0 \\
0 \\
0\end{array}$ & $\begin{array}{l}0 \\
0 \\
0\end{array}$ & $\begin{array}{l}0 \\
0 \\
0\end{array}$ \\
\hline & Negative & $\begin{array}{ll}\text { Positive } & 0 \\
\text { Negative } & 0 \\
\text { Not examined } & 0\end{array}$ & $\begin{array}{l}0 \\
0 \\
0\end{array}$ & $\begin{array}{l}0 \\
0 \\
0\end{array}$ & $\begin{array}{l}0 \\
0 \\
0\end{array}$ \\
\hline & $\begin{array}{l}\text { Not } \\
\text { examined } \\
46\end{array}$ & $\begin{array}{lr}\text { Positive } & 0 \\
\text { Negative } & 0 \\
\text { Not examined } & \mathbf{4 6}\end{array}$ & $\begin{array}{l}0 \\
0 \\
9\end{array}$ & $\begin{array}{r}0 \\
0 \\
37\end{array}$ & $\begin{array}{l}0 \\
0 \\
0\end{array}$ \\
\hline
\end{tabular}

general condition, and, although of no ultimate significance to the patient, nine cases $(19 \%)$ had malignant cells in the sputum.

In only 97 cases, therefore, was detailed cytological investigation necessary, and in only 23 $(23 \%)$ was it of diagnostic value to the clinician. It is of interest that this figure is almost the same as the over-all rate of positives.

Table III shows the number of samples of sputum that had to be examined in each of the 47 cases before malignant cells could be identified. Whilst, obviously, the more specimens examined the more likely malignant cells are to be discovered, three to six samples appears to be a reasonable number to examine before accepting a negative result.

T A B L E I I I

SPECIMEN OF SPUTUM IN WHICH MALIGNANT CEIIS WERE FIRST DISCOVERED IN THE 47 POSITIVE CASES

\begin{tabular}{|c|c|c|c|c|c|}
\hline \multicolumn{4}{|c|}{ Specimen } & No. & $\%$ \\
\hline $\begin{array}{l}\text { First } \\
\text { Second } \\
\text { Third } \\
\text { Fourth } \\
\text { Fifth } \\
\text { Sixth } \\
\text { Seventh }\end{array}$ & $\begin{array}{l}\ldots \\
\cdots \\
\cdots \\
\cdots \\
\cdots \\
\ldots\end{array}$ & $\begin{array}{l}\ldots \\
\cdots \\
\ldots \\
\cdots \\
\ldots\end{array}$ & $\begin{array}{l}\cdots \\
\cdots \\
\cdots \\
\cdots \\
\ldots\end{array}$ & $\begin{array}{l}31 \\
39 \\
44 \\
45 \\
46 \\
46 \\
47\end{array}$ & $\begin{array}{r}65 \\
83 \\
93 \\
95 \\
98 \\
98 \\
100\end{array}$ \\
\hline
\end{tabular}

HISTOLOGICAL TYPES OF RRONCHIAL CARCINOMA In one case, two carcinomata were present in one lung, one an epidermoid and the other an oat-cell carcinoma. Both types of tumour were actually diagnosed separately on the features of the malignant cells found in the sputum, so that there was a total of 48 carcinomata giving rise to malignant cells in the sputum. The distribution of these tumours and the relationship between the finding of malignant cells in the sputum and the histological type of the tumour is shown in Table IV.

T A B L E I V

RELATIONSHIP BETWEEN MALIGNANT CELI S IN SPUTUM AND HISTOLOGICAL TYPE OF TUMOUR

\begin{tabular}{|c|c|c|c|c|}
\hline \multirow[b]{2}{*}{ Type of Tumour } & \multicolumn{3}{|c|}{ No. of Carcinomata } & \multirow{2}{*}{$\begin{array}{l}\text { Distri- } \\
\text { bution } \\
\text { of All } \\
\text { Carcino- } \\
\text { mata } \\
\text { in the } \\
\text { Series }\end{array}$} \\
\hline & $\begin{array}{l}\text { Malignant } \\
\text { Cells in } \\
\text { Sputum }\end{array}$ & $\begin{array}{l}\text { No } \\
\text { Malignant } \\
\text { Cells in } \\
\text { Sputum }\end{array}$ & $\begin{array}{l}\text { Total No. } \\
\text { in which } \\
\text { Sputum } \\
\text { was } \\
\text { Examined }\end{array}$ & \\
\hline $\begin{array}{l}\text { Epidermoid } \\
\text { Adenocarcinoma }\end{array}$ & $\begin{array}{r}21 \\
1 \\
8 \\
5\end{array}$ & $\begin{array}{l}55 \\
15 \\
13 \\
10\end{array}$ & $\begin{array}{l}76 \\
16 \\
21 \\
15\end{array}$ & $\begin{array}{l}86 \\
18 \\
24 \\
15\end{array}$ \\
\hline $\begin{array}{l}\text { cinoma } \\
\text { Not finally diagnosed }\end{array}$ & 12 & $\begin{array}{r}2 \\
63\end{array}$ & $\begin{array}{r}3 \\
75\end{array}$ & $\begin{array}{r}3 \\
78\end{array}$ \\
\hline Total & 48 & 158 & 206 & 224 \\
\hline
\end{tabular}

This shows that, with the exception of adenocarcinoma, there is little difference between the distribution of the tumours in cases with or without malignant cells in the sputum, and no particular type of tumour appears to be more prone to shed malignant cells than the others.

Table $\mathrm{V}$ shows a similar analysis of bronchial secretions and type of tumour. Epidermoid and oat-cell carcinomata predominate, and this is probably explained by the fact that these tumours are usually situated at the hilum.

TABLE V

RELATIONSHIP BETWEEN MALIGNANT CELLS IN BRONCHIAL SECRETIONS AND HISTOLOGICAL TYPE OF TUMOUR

\begin{tabular}{|c|c|c|c|c|}
\hline \multirow[b]{2}{*}{$\begin{array}{c}\text { Type } \\
\text { of Tumour }\end{array}$} & \multicolumn{3}{|c|}{ No. of Carcinomata } & \multirow{2}{*}{$\begin{array}{c}\text { Distri- } \\
\text { bution } \\
\text { of All } \\
\text { Carcino- } \\
\text { mata } \\
\text { in } \\
\text { the } \\
\text { Series }\end{array}$} \\
\hline & $\begin{array}{c}\text { Malignant } \\
\text { Cells in } \\
\text { Bronchial } \\
\text { Secretions }\end{array}$ & $\begin{array}{c}\text { No } \\
\text { Malignant } \\
\text { Cells in } \\
\text { Bronchial } \\
\text { Secretions }\end{array}$ & $\begin{array}{c}\text { Total No. } \\
\text { in which } \\
\text { Bronchial } \\
\text { Secretions } \\
\text { were } \\
\text { Examined }\end{array}$ & \\
\hline $\begin{array}{l}\text { Epidermoid } \\
\text { Adenocarcinoma } \\
\text { Oat-cell .. } \\
\text { Anaplastic carcinoma } \\
\text { Alveolar-cell car- } \\
\quad \text { cinoma } \\
\text { Not finally diagnosed }\end{array}$ & $\begin{array}{r}16 \\
1 \\
10 \\
0 \\
0 \\
3\end{array}$ & $\begin{array}{r}43 \\
10 \\
8 \\
8 \\
3 \\
3 \\
48\end{array}$ & $\begin{array}{r}59 \\
11 \\
18 \\
8 \\
3 \\
51\end{array}$ & $\begin{array}{r}86 \\
18 \\
24 \\
15 \\
\\
3 \\
78\end{array}$ \\
\hline Total & 30 & 120 & 150 & 224 \\
\hline
\end{tabular}


SITE OF THE TUMOUR An attempt was made to ascertain the site of each bronchial carcinoma where this could be done with reasonable accuracy. Table VI shows an analysis of the results for both sputum and bronchial secretions. The sites are

\section{TABLE VI}

RELATIONSHIP BETWEEN THE PRESENCE OF MALIGNANT CELLS IN THE SPUTUM AND BRONCHIAL SECRETIONS AND THE SITE OF THE TUMOUR

\begin{tabular}{|c|c|c|c|c|c|c|}
\hline \multirow{3}{*}{$\begin{array}{c}\text { Site } \\
\text { of } \\
\text { Tumour }\end{array}$} & \multicolumn{3}{|c|}{ Sputum } & \multicolumn{3}{|c|}{ Bronchial Secretions } \\
\hline & \multicolumn{2}{|c|}{ Malignant Cells } & \multirow{2}{*}{ Total } & \multicolumn{2}{|c|}{ Malignant Cells } & \multirow{2}{*}{ Total } \\
\hline & Positive & Negative & & Positive & Negative & \\
\hline $\begin{array}{l}\text { Hilar } . . \\
\text { Central } \\
\text { Peripheral }\end{array}$ & $\begin{array}{r}35 \\
3 \\
5\end{array}$ & $\begin{array}{r}104 \\
7 \\
12\end{array}$ & $\begin{array}{r}139 \\
10 \\
17\end{array}$ & $\begin{array}{r}28 \\
1 \\
1\end{array}$ & $\begin{array}{r}85 \\
6 \\
15\end{array}$ & $\begin{array}{r}113 \\
7 \\
16\end{array}$ \\
\hline Total & 43 & 123 & 166 & 30 & 106 & 136 \\
\hline
\end{tabular}

described as hilar, central, and peripheral ; central referring to a position in the centre of the lung parenchyma. The distribution of the tumours giving rise to malignant cells in the sputum does not differ significantly from the total distribution, and therefore a peripheral tumour, or one situated in the middle of the lung, appears just as likely to give rise to malignant cells as one situated at the hilum. In bronchial secretions, however, malignant cells are more likely to come from tumours situated at the hilum of the lung, and this is not surprising when one considers the nature of the secretions.

SECONDARY CARCINOMA OF LUNG Of 10 cases with secondary carcinoma of the lung, the sputum was examined in seven, with one positive result ; bronthe pleural fluid in one case with no positives. The single positive was from a case of hypernephroma with secondaries in the lung. The figures are, of course, far too small for any conclusions to be drawn, but they are not very encouraging.

ROLE OF EXFOLIATIVE CYTOLOGY IN PROGNOSIS As has been clearly recognized by all authors, the final outcome for patients with carcinoma of chial secretions were examined in four cases and

the bronchus is extremely disappointing. We were able to carry out a full follow-up on 200 cases, and, of these, 72 had radical surgery. This compares very favourably with the usually expected operability rate of $25 \%$.

The average duration of life of the 128 patients not successfully operated on was four months. $\vec{P}$ These included patients who survived three and four years, and nine patients who survived from $\vec{\omega}$ one to two years. Of the 72 cases operated upon, the average duration of life was 18 months. These $\vec{x}$ include 19 patients still alive from two to $\overrightarrow{0}$ seven years, with an average duration of three $\dot{\omega}$ years; five survived for more than four years, which approximates to the usually accepted $5 \% 0$ five-year survival rate.

SIGNIFICANCE OF MALIGNANT CELLS IN SPUTUM $\vec{z}$ Table VII compares patients with and without malignant cells in the sputum. There is remark- $\vec{\bullet}$ ably little difference between the two groups. Similar proportions of cases were inoperable because of poor general health and secondary spread. A similar proportion of cases in each group was operated on successfully, and the final outcome is very much the same. The only difference that approaches significance is that, in the $\stackrel{\mathbb{Q}}{\varrho}$ group with malignant cells in the sputum, a greater $\overrightarrow{\overrightarrow{0}}$ proportion of patients underwent an operation 3 which had to be abandoned because local spread had gone too far for resection to be undertaken. So in effect the presence of malignant cells in the sputum indicated a slightly graver outlook for the patient and a warning to the surgeon that the $\underset{\times}{\stackrel{0}{x}}$ operation might have to be abandoned.

SIGNIFICANCE OF MALIGNANT CELLS IN BRONCHIAL SECRETIONS Table VIII compares patients with and without malignant cells in the bronchial 0 secretions. Again the groups are very similar. There is very little difference in the over-all $\frac{7}{0}$ duration of life; the proportion of those surviving after a successful operation is very much the same. N However, a greater proportion of patients without $N$ malignant cells in the secretions had a successful N

T A B L E V I I

ANALYSIS OF CASES WITH AND WITHOUT MALIGNANT CELLS IN SPUTUM, COMPARING OPERABILITY AND SURVIVAL

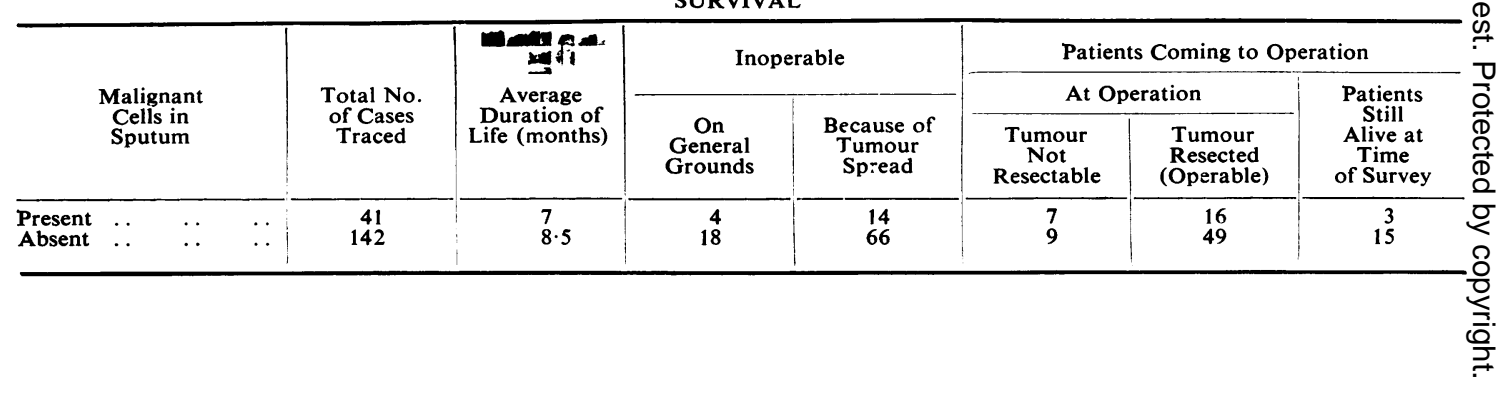


TABLE VIII

ANALYSIS OF CASES WITH AND WITHOUT MALIGNANT CELLS IN BRONCHIAL SECRETIONS, COMPARING OPERABILITY AND SURVIVAL

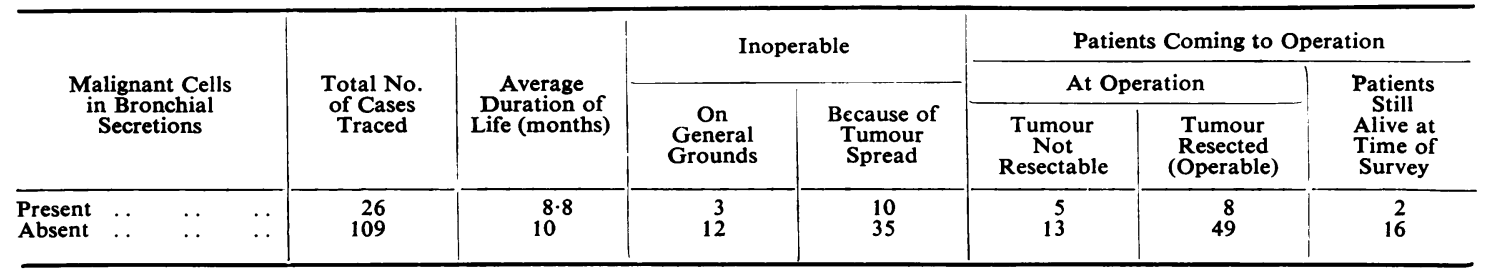

TABLE IX

COMPARISON OF OPERABILITY, SURVIVAL, AND HISTOLOGICAL TYPE OF TUMOUR

\begin{tabular}{|c|c|c|c|c|c|c|c|c|c|}
\hline \multirow{2}{*}{\multicolumn{4}{|c|}{ Type of Tumour }} & \multicolumn{3}{|c|}{ Inoperable on All Grounds } & \multicolumn{3}{|c|}{ Tumour Resected (Operable) } \\
\hline & & & & $\begin{array}{c}\text { Average } \\
\text { Duration of } \\
\text { Life (months) }\end{array}$ & $\begin{array}{l}\text { No. of } \\
\text { Patients } \\
\text { Traced }\end{array}$ & $\begin{array}{l}\text { No. of } \\
\text { Patients } \\
\text { Surviving }\end{array}$ & $\begin{array}{c}\text { Average } \\
\text { Duration of } \\
\text { Life (months) }\end{array}$ & $\begin{array}{c}\text { No. of } \\
\text { Patients } \\
\text { Traced }\end{array}$ & $\begin{array}{l}\text { No. of } \\
\text { Patients } \\
\text { Surviving }\end{array}$ \\
\hline $\begin{array}{l}\text { Epidermoid } \\
\text { Adenocarcinoma .. } \\
\text { Oat-cell carcinoma } \\
\text { Anaplastic ,, } \\
\text { Alveolar-cell ,", }\end{array}$ & $\begin{array}{l}\cdots \\
\cdots \\
\cdots \\
\cdots\end{array}$ & $\begin{array}{l}\cdots \\
\cdots \\
\cdots \\
\cdots\end{array}$ & $\begin{array}{l}\cdots \\
\cdots \\
\cdots \\
\cdots \\
\cdots\end{array}$ & $\begin{array}{l}5 \cdot 6 \\
4 \cdot 2 \\
2.7 \\
1.9 \\
-\end{array}$ & $\begin{array}{r}35 \\
9 \\
12 \\
9 \\
-\end{array}$ & $\begin{array}{l}0 \\
0 \\
0 \\
0 \\
-\end{array}$ & $\begin{array}{l}19 \cdot 8 \\
16 \cdot 5 \\
18 \cdot 6 \\
14 \cdot 1 \\
16 \cdot 5\end{array}$ & $\begin{array}{r}36 \\
7 \\
8 \\
6 \\
3\end{array}$ & $\begin{array}{r}12 \\
2 \\
2 \\
2 \\
2\end{array}$ \\
\hline
\end{tabular}

resection than those with malignant cells, $\chi^{2}=1.2$ $(0.3>\mathrm{P}>0.2)$. Also, in the group with malignant cells in the bronchial secretions, more operations had to be abandoned because of unexpected tumour spread than in the group without malignant cells, $\chi^{2}=0.95(0.5>P>0.3)$.

RELATIONSHIP BETWEEN MALIGNANT CELLS IN PLEURAL FLUID AND PROGNOSIS In cases of carcinoma of the bronchus associated with pleural effusion, the presence or absence of malignant cells in the pleural fluid appeared to have no influence on the prognosis. Practically all these cases were either considered to be or proved to be inoperable because of poor general health or secondary spread. The prognosis was uniformly bad, death usually occurring within one month of the diagnosis being made.

RELATIONSHIP BETWEEN PROGNOSIS AND TYPE OF TUMOUR This is shown in Table IX; the figures are unfortunately too small for any satisfactory conclusion to be drawn. They suggest that the epidermoid carries a somewhat better prognosis than the other types of tumour, which has been clearly shown by Cleland (1958), but our results are by no means clear cut.

\section{DISCUSSION AND CONCLUSIONS}

On the whole we felt that the results were disappointing, and it may well be that this was due to deficiencies in technique. This series was, however, simply an analysis of work routinely undertaken by the laboratory, and as such it gives an indication of the value of the work done. There is no doubt that the examination of multiple specimens of sputum is essential, and probably negative results on one or two specimens should be disregarded. The laying down of a rigid ward procedure for the collection of multiple specimens of sputum would undoubtedly increase the percentage of positive results, although it often becomes expedient to abandon such a procedure in practice. The increase in work thus involved would require a much more careful clinical selection of patients and would prevent the wide application of the method as a screening test.

The insistence that the specimen should be only true sputum, as judged by the presence of dustladen macrophages, would also increase the percentage of positives. It is, however, often difficult to be absolutely certain about rejecting a specimen, and there are some patients who find it difficult or impossible to produce sputum. This has stimulated the development of the use of innocuous agents to produce cough and sputum. In 1958, Bickerman, Sproul, and Barach reported the use of a propylene glycol nebulizer ; further results using this method were published in 1960 by Barach, Bickerman, Beck, Nanda, and Pons and by Berkson and Snider, and in 1961 by Olsen, Froeb, and Palmer. The published figures are only small so far, but Umiker (1961) considers that the artificial induction of sputum has not only increased the accuracy of pulmonary cytology in 
the diagnosis of bronchial carcinoma but has broadened the scope of its applicability. Also in 1958, Allan, Whittlesey, and Haroutunian used the inhalation of sulphur dioxide to stimulate the production of sputum, and in 1960 Allan, Whittlesey, and Kelley reported a $98.4 \%$ positive cell study in 64 cases of carcinoma of the lung without cough. Fontana, Carr, Woolner, and Miller (1962), in an evaluation of the methods of sputum induction, concluded that the procedure was effective and valuable but that neither method was superior. Obviously, such a potentially valuable new technique in sputum cytology should be carefully investigated since it apparently offers increased accuracy without increasing the burden of work on the laboratory.

Swierenga (1963) discusses methods of obtaining material for cytological diagnosis in bronchial carcinoma. He induces sputum by tracheal lavage with saline and water and also describes bronchial curettage, bronchial swabbing, and gland puncture through the carina. We have no experience of these methods and do not think they are widely practised in this country. They obviously have only a limited application.

Every cytologist considers that he uses the best technique. Most rely upon the original Papanicolaou (1954) technique, although there is now a tendency to concentrate on the examination of specially selected areas, particularly bloodstained ones. The technique we use is probably not widely known; we prefer it because it ensures immediate fixation and avoids any distortion of the cells due to drying. The picture produced by staining with haematoxylin and eosin is directly comparable with that of ordinary tissue sections, and, if necessary, an extensive examination of the material can be carried out by serial sectioning. It is interesting that Olsen et al. (1961) also considered the preparation of a similar 'cell-block' to be advantageous. The method is very popular with technicians because of the ease of handling the material, although the actual preparation of the slide takes longer than the smear method. However, at the present time, most cytologists would agree with Russell, Neidhardt, Mountain, Griffith, and Chang (1963), who conclude that multiple specimens are more important than specific methods and that several areas from each specimen should be examined. These authors also describe a technique of membrane filtration concentration of the sputum based on methods described by Seal (1956), Haynes (1942), and Farber, Pharr, Wood, and Gorman (1953). This appears to be an interesting and stimulating new approach to sputum .cytology, but unfortunately the published figures for this method do not indicate any great increase in accuracy.

We found it disappointing that in no case did the finding of malignant cells in the sputum provide the first sign of malignant disease in the lung. Even in those patients subjected to prolonged observation before malignancy occurred, the presence of malignant cells was not the first evidence of the disease. The examination of the sputum for malignant cells, by the method adopted, can in no way be considered as a simple satisfactory screening test for carcinoma.

In the majority of cases of bronchial carcinoma the diagnosis was confidently made by the usual 6 clinical methods. Exfoliative cytology has not 은 superseded these, neither does it confer any special $\vec{\longrightarrow}$ benefits ; in fact it is not required as a routine procedure and may give rise to considerable waste of time and expenditure in the laboratory. This is $\vec{\theta}$ perhaps now becoming more generally recognized. $\$$ As Farber (1961) has pointed out, the years of experience considerably tempered the optimism of the enthusiasts of pulmonary cytology, and, although an accurate cytological technique has been developed, its clinical application has not been as rewarding as was anticipated.

We conclude that exfoliative cytology has failed to alter radically the diagnosis and prognosis of carcinoma of the bronchus as it was hoped it would, and it is simply a useful adjunct to the well tried methods of investigation. We feel that the real value of the search for malignant cells in the sputum lies in the close co-operation between the clinician and the pathologist in the difficult, suspicious case when other methods have failed. When it is decided to examine the sputum for malignant cells, multiple specimens of true earlymorning sputum must be examined. Care should be taken to see that the specimen is in fact sputum $\frac{D}{0}$ and that it has been passed directly into fresh fixative. At least three, and preferably six, $N$ specimens should be examined. Even so, only in N about $25 \%$ of cases can the clinician expect any $\mathrm{N}$ help from the pathologist. Our figures are $\omega$ remarkably similar to those of Umiker (1961), who found that in $25 \%$ of cases of bronchial carcinoma the finding of malignant cells in the sputum, bronchial secretions or pleural fluid? provided the only definite evidence of a carcinoma ${ }^{\circ}$ before thoracotomy or necropsy. It is in these $\vec{D}$ difficult cases that the development of mutual trust $\frac{\rho}{\Phi}$ between the clinician and the pathologist is most $\stackrel{\mathbb{2}}{2}$ important, and the reporting of doubtful or 2 abnormal cells suspicious of malignancy may be $\delta$ 
of great value. Little harm appears to come to patients because of the occasional unfortunate reporting of false positives. It seems likely that with the more readily available thoracic services and the decreasing surgical risk, exploratory thoracotomy will be used more frequently and provide a more realistic approach to the early diagnosis of lung cancer.

In this series it appeared that malignant cells were shed into the sputum by almost a constant proportion (about 25\%) of bronchial carcinomata, whichever way the series was analysed. Malignant cells were shed equally by all histological types of bronchial carcinomata, with the exception of adenocarcinoma, and by tumours situated anywhere in the lungs. We must therefore look for some other factor that is responsible for some tumours shedding cells while others do not. It may simply be a matter of tumour breakdown and necrosis: whilst this is difficult to estimate and was not attempted in this series, it would perhaps provide an explanation of why the prognosis in patients with malignant cells seemed to be slightly worse than in those without malignant cells. In this respect it is worth recording that our findings differ from those of Umiker (1961), who found that hilar tumours and those in the lower lobe most commonly shed malignant cells, but he noted that the larger peripheral tumours of more than $5 \mathrm{~cm}$. diameter shed malignant cells as frequently as the hilar tumours. In his series, apparently the size of the hilar tumours had no bearing on their ability to shed malignant cells.

The finding of malignant cells in bronchial secretions seldom provided more information than bronchoscopy and biopsy. There were positive findings in five $(9.6 \%)$ of 51 patients in whom bronchoscopy and biopsy were negative. The knowledge that the bronchoscopy or biopsy was positive did not appear to influence unduly the finding of malignant cells in the bronchial secretions ; the secretions were positive in $25(25.5 \%)$ of 98 patients from whom secretions were taken and in whom bronchoscopy was considered to give positive evidence of carcinoma; and the secretions were positive in $19(29 \%)$ of 64 patients in whom biopsy was positive. Here again the proportion of tumours giving rise to malignant cells in the secretions appears to be fairly constant, but oat-cell and epidermoid carcinomata more commonly gave rise to malignant cells than other types of tumour. We consider that this was most likely explained by the fact that these tumours are usually situated at the hilum of the lung, and it is not surprising that hilar tumours most com- monly give rise to malignant cells in bronchial secretions.

So far as we could judge, exfoliative cytology appeared to have little value in secondary carcinoma of the lung, and this would presumably depend on whether or not the secondary was in connexion with the bronchus.

It seemed to us that patients with malignant cells in either the sputum or the bronchial secretions had a slightly worse prognosis than those without malignant cells, and a greater proportion of operations in the positive group had to be abandoned because of unexpected tumour spread. Although the differences between groups did not actually attain statistical significance, this did suggest to us what is surely a reasonable assumption, namely, that malignant cells are more likely to be shed by tumours that have become well established and have been subject to necrosis and ulceration. This may perhaps be of some help to the surgeon in his assessment of the case.

\section{SUMMARY}

Seven hundred and thirty-six patients examined for malignant cells in the sputum, bronchial secretions, or pleural fluid are reviewed. They include 223 cases of bronchial carcinoma and 10 cases of secondary carcinoma of the lung.

False positives were reported in $0.48 \%$ of cases in which the bronchial secretions had been examined and in $0.65 \%$ of cases in which the sputum had been examined. Positives were reported in $23 \%$ of cases in which the sputum was examined, in $20 \%$ of cases in which bronchial secretions were examined, and in $35 \%$ of the cases in which pleural fluid was examined.

Malignant cells in the sputum were shed by all types of tumour equally, with the exception of adenocarcinoma, and by tumours anywhere in the lung ; and malignant cells were found in bronchial secretions more commonly from oat-cell and epidermoid carcinomata and tumours situated at the hilum of the lung.

It was considered that patients with malignant cells in the sputum and bronchial secretions had a slightly worse prognosis than those without malignant cells.

It was concluded that exfoliative cytology has in no way superseded the usual methods of investigation, and has failed as a simple screening test. It is best reserved for those cases in which other methods of investigation have failed, and it should then be carried out with great attention 
to technical detail and by the examination of multiple specimens.

Our thanks are due to Dr. M. I. Jackson for allowing us access to the clinical records of his patients ; to the technical and clerical staff of the Department of Pathology, St. Woolos Hospital, for the preparation of the material ; and to Professor J. Gough for criticism of the script.

\section{REFERENCES}

Allan, W. B., Whittlesey, P., and Haroutunian, L. M. (1958). The use of sulfur dioxide as a diagnostic aid in pulmonary cancer. Cancer, 11, 938.

- and Kelley, E. B. (1960). The results of the experimental use of sulfur dioxide in the production of material for cell studies in lung cancer. Ann. intern. Med., 52, 326.

Bamforth, J., and Osborn, G. R. (1958). Diagnosis from cells. $J$. clin. Path., 11, 473.

Barach, A. L., Bickerman, H. A., Beck, G. J., Nanda, K. G. S., and Pons, E. R. (1960). Induced sputum as a diagnostic technique for cancer of the lungs and for mobilization of retained secretions. Arch. intern. Med., 106, 230

Berkson, D. M., and Snider, G. L. (1960). Heated hypertonic aerosol in collecting sputum specimens for cytological diagnosis. J. Amer. med. Ass., 173, 135.

Bickerman, H. A., Sproul, E. E., and Barach, A. L. (1958). An aerosol method of producing bronchial secretions in human aerosol method of producing bronchial secretions in human Chest $, 33,347$. Boucot, K. R., and Sokoloff, M. J. (1955). Is survey cancer of the
lung curable? Ibid., 27,369 .

Cleland W P (1958). In Carcinoma of the Lung-J. R. Bignall, p. 228 [Vol. 1 of Monographs on Neoplastic Disease at Various Sites, ed. D. W. Smithers]. Livingstone, Edinburgh

Clerf, L. H., and Herbut, P. A. (1950). The value of cytological diagnosis of pulmonary malignancy. Amer. Rev. Tuberc., 61, 60.

Farber, S. M. (1961). Clinical appraisal of pulmonary cytology. $J$. Amer. med. Ass. 175, 345 .

- Pharr, S. L., Wood, D. A., and Gorman, R. D. (1953). The mucolytic and digestive action of trypsin in the preparation of sputum for cytologic study. Science, $117,687$.

Fontana, R. S., Carr, D. T., Woolner, L. B., and Miller, F. K. (1962). An evaluation of methods of inducing sputum production in patients with suspected carcinoma of lung. Proc. Mayo Clin., 37,113

Haynes, E. (1942). Trypsin as a digestant of sputum and other body fluids preliminary to examination for acid-fast bacilli. $J$. Lab. clin. Med., 27, 806.

Olsen, C. R. Froeb, H. F., and Palmer, L. A. (1961). Sputum cytology after inhalation of heated propylene glycol. J. Amer. med. Ass. $\omega$ 178, 668.

Papanicolaou, G. N. (1954). Atlas of Exfoliative Cytology. Harvard University Press, Cambridge, Mass.

Russell, W. O., Neidhardt, H. W., Mountain, C. F., Griffith, K. M., 음 and Chang, J. P. (1963). Cytodiagnosis of lung cancer. Acta cytol. (Philad.), 7, 1

Seal, S. H. (1956). A method for concentrating cancer cells suspended in large quantities of fluid. Cancer 9,866 .

Swierenga, J. (1963). Methods of obtaining material for cytological diagnosis in bronchial carcinoma. Excerpta med. (Amst.), Sect. $X V, 16,139$

Umiker, W. O. (1961). A new vista in pulmonary cytology; aerosol induction of sputum. Dis. Chest, 39,512 .

- (1961). The current role of exfoliative cytopathology in the routine diagnosis of bronchogenic cancer. Ibid., 40, 154.

Williams, S. (1961). The cytological diagnosis of lung cancer. Med. J. Aust., 1, 233. 